\title{
Research on selectivity removing SO2 from flue gas with a novel
}

\section{absorbent}

\section{Wanren Chen ${ }^{1}$, Hua Li ${ }^{1 *}$, Xiaoshuang Chen ${ }^{2}$}

1. Integrated Designing and Researching Institute, Zhengzhou University, Zhengzhou, Henan, China, 450001,

Email:wrchen@zzu.edu.cn

1. School of Chemical and Energy Engineering, Zhengzhou University, Zhengzhou, Henan, China, 450001, *Email: lihua@zzu.edu.cn

2. School of Energy and Power Engineering, Xi'an Jiaotong University, Xi'an, Shanxi, China, 710049,

Email: chxshuang@sina.com

\begin{abstract}
:
Compared with the traditional methods of removal $\mathrm{SO}_{2}$ from flue gas, the organic solvent absorption has some advantages as low investment, high $\mathrm{SO}_{2}$ absorption efficiency and desorption efficiency. For the industrial application of organic solvent absorption as soon as possible, some laboratory research on selectively removing $\mathrm{SO}_{2}$ and $\mathrm{NOx}$ from flue gas in the presence of $\mathrm{CO}_{2}$ and an enlarged experiment has been done with a novel absorbent of $\mathrm{Mn}$ (II) + DMSO. The effect on desulfurization selectivity for absorbents is studied. And the regeneration capacities for absorbent are researched. The result shows that the novel absorbent has not only strong desulfurization efficiency, but also good selectivity for $\mathrm{SO}_{2}$ and $\mathrm{CO}_{2}$, the feasibility of desulfurization absorbent has been proved.
\end{abstract}

Keyword: selectivity; desulfurization; flue gas; the enlarged experiment; DMSO +Mn (II)

\section{Council for Innovative Research}

Peer Review Research Publishing System

Journal: Journal of Advances in Chemistry

Vol 2, No. 2

editor@cirworld.com

www.cirworld.com, member.cirworld.com 


\section{Introduction}

Removal of $\mathrm{SO}_{2}, \mathrm{CO}_{2}$ and $\mathrm{NOx}$ from flue gas is one of very important research projects in the world. In the previous literature [1], some laboratory research on removing $\mathrm{SO}_{2}$ from flue gas with DMSO absorbent have been studied. But removing $\mathrm{SO}_{2}$ and $\mathrm{NOx}$ from flue gas in the presence of $\mathrm{CO}_{2}$ had not been reported. As we know, there is not only sulfur dioxide, but also a lot of $\mathrm{CO}_{2}$ in flue gas from industrial emissions. Because $\mathrm{SO}_{2}$ and $\mathrm{CO}_{2}$ are all acidic gases, and the concentration of sulfur dioxide is much lower than carbon dioxide in the flue gas. If the absorbent has not selectivity for acid gas such as $\mathrm{SO}_{2}$ and $\mathrm{CO}_{2}$, it will lead to a serious decrease for desulfurization efficiency because the absorbent absorbs a large number of $\mathrm{CO}_{2}$, therefore the good selectivity for $\mathrm{SO}_{2}$ and $\mathrm{CO}_{2}$ is necessary in order to reach higher desulfurization efficiency. Therefore, in this paper, based on our selected organic absorbent DMSO [2-7], a small amount of Mn (II) catalyst is added in the system of organic solvent absorption, it is found that the desulfurization efficiency with a small amount of Mn (II) catalyst has been much improved compared with pure physical solvent of DMSO, Mn (II) played a significant catalytic role [8]. In order to further verify the selectively desulfurization effect of Mn (II) + DMSO. Some laboratory research on selectively removing $\mathrm{SO}_{2}$ and $\mathrm{NOx}$ from flue gas with $\mathrm{Mn}$ (II) + DMSO absorbent have been carried out. The research provides a basis for the industrial application of flue gas desulfurization technology.

\section{Experimental Sections}

The experiment includes two sections: (1) the selectivity absorption experiment of $\mathrm{Mn}$ (II) + DMSO on removal efficiency of $\mathrm{SO} 2$ and $\mathrm{NOx}$ in the presence of $\mathrm{CO} 2$. (2) the enlarged experiment.

\subsection{The selectively absorption experiment of $\mathrm{Mn}$ (II) + DMSO on removal efficiency of $\mathrm{SO}_{2}$ and NOx in the presence of $\mathrm{CO}_{2}$.}

The technological process of the selectivity SO2 removal experiment is shown in Figure 1. Sulfur dioxide with a mole fraction purity $\times(\mathrm{SO} 2) \geq 0.997$, carbon dioxide with a mole fraction purity $\times\left(\mathrm{CO}_{2}\right) \geq 0.99$, $\mathrm{NO}$ and $\mathrm{NO}_{2}$ with a mole fraction purity $x(\mathrm{NOx}) \geq 0.99$, nitrogen of purity $x(\mathrm{~N} 2) \geq 0.99999$ are obtained from cylinders. Sulfur dioxide, carbon dioxide, NOx and nitrogen are mixed by a gas mixer with static agitation to simulate the flue gas. A flowrator is used to control the gas flow. $\mathrm{CO}_{2}$ is analyzed by $\mathrm{CO} 2$ analyzer (type RD-7AG, Nanjing, China). Nitrogen Oxides is analyzed by NOx analyzer (type NA-721 Nitrogen Oxides Analyzer, China). $\mathrm{O}_{2}$ is analyzed by AUS-gas analyzer with gas absorption method. $\mathrm{A} \mathrm{SO}_{2}$ analyzer (type NTS 100, Nanjing, China) is used for the $\mathrm{SO}_{2}$ analysis of the gas phase from the inlet and tail gases. The $\mathrm{SO}_{2}$ concentration in the gas phase before and after absorption is analyzed by $\mathrm{SO} 2$ analyzer, and then the removal efficiency is calculated.

The removal efficiency, $\%=\frac{C_{0}-C}{C_{0}} \times 100 \%$

In which, $\mathrm{C}_{0}-\mathrm{The} \mathrm{SO}_{2}$ or NOx concentration before absorption;

$\mathrm{C}$ - The $\mathrm{SO}_{2}$ or NOx concentration after absorption

All the chemical reagents used are AR grade. Purified and deionized water of conductivity $<0.06 \mu S \cdot \mathrm{cm}-1$ is used in the measurements. 


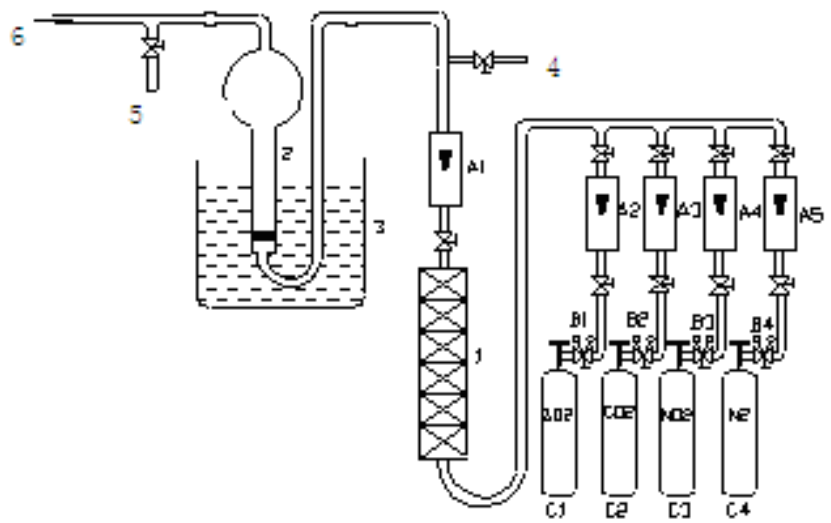

Fig. 1 The technological process of $\mathrm{SO}_{2}$ absorption

$\mathrm{C} 1: \mathrm{SO}_{2}$ cylinder, $\mathrm{C} 2: \mathrm{CO}_{2}$ cylinder, $\mathrm{C} 3: \mathrm{NO}_{x}$ cylinder, $\mathrm{C} 4: \mathrm{N}_{2}$ cylinder, B1-B4: walve, A1-A5: flowrator,

1- a gas mixer with static agitation unit,

4-inlet gas to $\mathrm{SO}_{2}$ analyzer,

\section{2-absorption tube}

5- outlet gas to $\mathrm{SO}_{2}$ analyzer,
3- constant temperature bath.

6- to fume hood

\subsection{The enlarged experiment}

The enlarged experimental apparatus is shown in Figure 2, the absorption tower is a packed tower, diameter is $25 \mathrm{~mm}$, inside packing diameter is $\Phi=5 \mathrm{~mm} \times 10 \mathrm{~mm}$. The regenerative tower is a packed tower of $25 \mathrm{~mm} \times 78 \mathrm{~mm}$, with heat preservation jacket. The flow and the direction of the absorption solution at rectifier bottom are controlled by the recycle pumps. $\mathrm{SO}_{2}, \mathrm{CO}_{2}, \mathrm{O}_{2}$ and $\mathrm{N}_{2}$ from cylinders are mixed by a gas mixer with static agitation to simulate the flue gas. $\mathrm{A}$ flowrator is used to control the gas flow. The mixed gas is absorbed through the saturation flask in absorption tower, $\mathrm{A} \mathrm{SO}_{2}$ analyzer (type NTS 100, Nanjing, China) is used for the $\mathrm{SO}_{2}$ analysis of the gas phase. The $\mathrm{SO}_{2}$ concentration of solution was measured by iodometric method.

The effect of ratio gas to liquid, rate of flow, temperature and inlet gas composition on the desulfurization selectivity is determined, and the absorption and desorption efficiency was measured.

Both $\mathrm{SO}_{2}$ removal efficiency and desulfurization selectivity are used as the evaluation index. The desulfurization selectivity is defined as follows,

Desulfurization selectivity $=\left[\mathrm{SO}_{2}\right]_{l} /\left[\mathrm{CO}_{2}\right]_{l}$

$\left[\mathrm{SO}_{2}\right]_{1:} \mathrm{SO}_{2}$ concentration of rich solution

$\left[\mathrm{CO}_{2}\right]$ : $\mathrm{CO}_{2}$ concentration of rich solution 


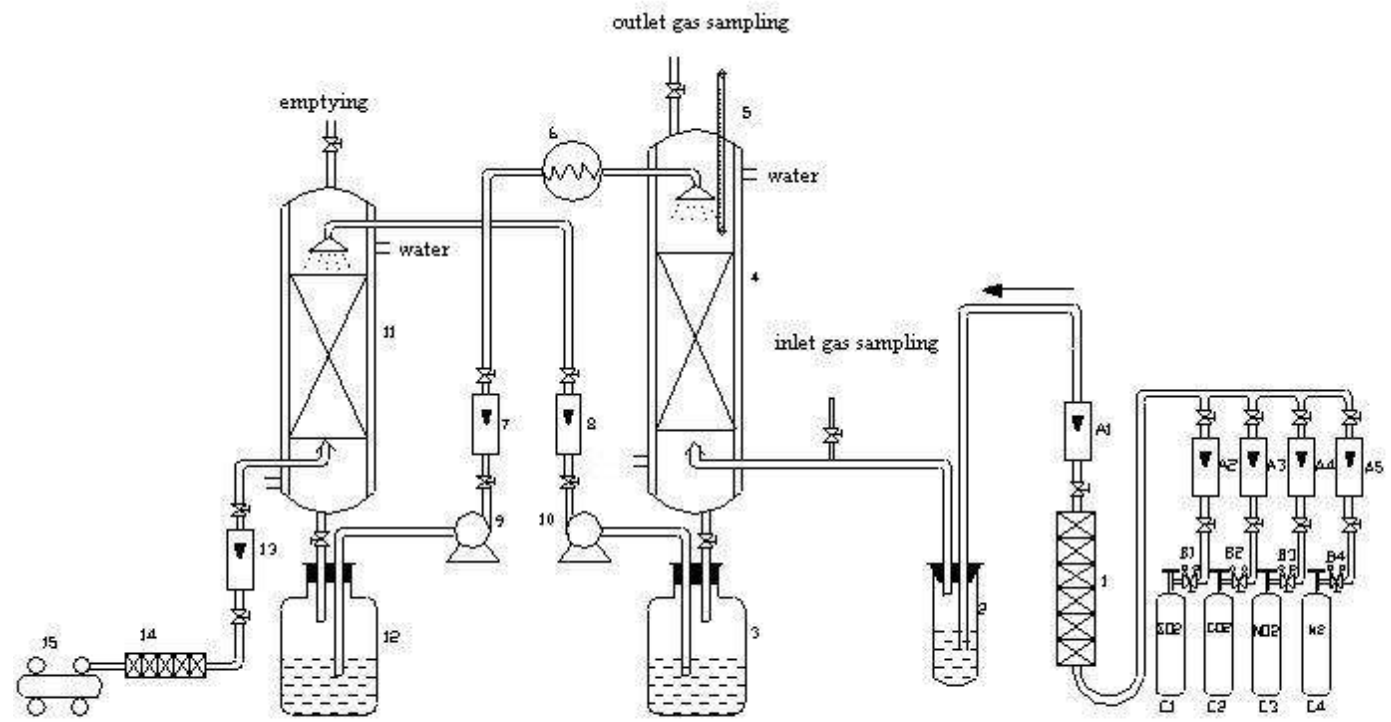

Fig. 2 The experimental apparatus of removing $\mathrm{SO}_{2}$

1 a gas mixer with static agitation unit 2.saturation flask 3.absorption $\mathrm{SO}_{2}$ flask 4.absorption tower 5 .thermometer 6.heater 7. flowmeter 8. flowrmeter 9.pump 10.pump 11.regenerative tower 12. absorption flask after desorption $\mathrm{SO}_{2}$ 13. flowrmeter 14.filter 15. air compressor

\section{Results and discussion}

3.1 The selectively absorption experiment of $\mathrm{Mn}$ (II) + DMSO on removal efficiency of $\mathrm{SO}_{2}$ and NOx in the presence of $\mathrm{CO}_{2}$

\subsubsection{The effect of Mn (II)+DMSO on the removal efficiency of $\mathrm{SO}_{2}$}

Experiment condition: temperature $303.15 \mathrm{~K}$, gas flow: $80 \mathrm{ml} / \mathrm{min}$, inlet $\mathrm{SO}_{2}$ concentration: $0.1792 \%$. The effect of $\mathrm{Mn}$ (II)+DMSO absorbent on the removal efficiency of $\mathrm{SO}_{2}$ is listed in Table 1, Mn (II) concentration is $0.03 \mathrm{~mol} / \mathrm{L}$.

Table 1 The effect of absorbent of Mn (II)+DMSO on the removal efficiency of $\mathrm{SO}_{2}$

\begin{tabular}{cccc}
\hline No inlet $\mathrm{SO}_{2}$ concentration, $\%$ & outlet $\mathrm{SO}_{2}$ concentration, \% & $\mathrm{SO}_{2}$ removal efficiency, \% \\
\hline 1 & 0.1806 & 0.0034 & 98.12 \\
2 & 0.1670 & 0.0024 & 98.56 \\
3 & 0.2608 & 0.0095 & 96.36
\end{tabular}

From Table 1, it can be seen that $\mathrm{Mn}(\mathrm{II})+\mathrm{DMSO}$ absorbent have high the removal efficiency for $\mathrm{SO}_{2}$, and the removal efficiency of $\mathrm{SO}_{2}$ increases with the decrease of inlet $\mathrm{SO}_{2}$ concentration.

\subsubsection{The selectively absorption effect of $\mathrm{Mn}$ (II) + DMSO on removal efficiency of $\mathrm{SO}_{2}$ in the presence of $\mathrm{CO}_{2}$}

Experiment condition: temperature $301.15 \mathrm{~K}$, gas flow: $140 \mathrm{~mL} \cdot \mathrm{min}^{-1}$, inlet $\mathrm{SO}_{2}$ concentration: $0.1893 \% \mathrm{SO}_{2}$, inlet $\mathrm{CO}_{2}$ concentration: $11.3 \% \mathrm{CO}_{2}$. The result is listed in Table 2 
Table 2 Selectivity absorption effect of $\mathrm{Mn}$ (II) + DMSO on removal efficiency of $\mathrm{SO}_{2}$ in the presence of $\mathrm{CO}_{2}$

\begin{tabular}{|c|c|c|c|c|c|c|}
\hline \multirow[b]{2}{*}{$\mathrm{t}, \mathrm{min}$} & \multicolumn{2}{|c|}{5} & \multicolumn{2}{|c|}{10} & \multicolumn{2}{|r|}{15} \\
\hline & $\begin{array}{c}\text { outlet } \\
\text { concentration, } \\
10^{-6}\end{array}$ & $\begin{array}{c}\text { removal } \\
\text { efficiency, } \\
\%\end{array}$ & $\begin{array}{c}\text { outlet } \\
\text { concentration, } \\
10^{-6}\end{array}$ & $\begin{array}{c}\text { removal } \\
\text { efficiency , \% }\end{array}$ & $\begin{array}{c}\text { outlet } \\
\text { concentration, } \\
10^{-6}\end{array}$ & removal efficiency ,\% \\
\hline $\mathrm{SO}_{2}$ & 2 & 99.89 & 5 & 99.44 & 5 & 99.44 \\
\hline \multirow[t]{2}{*}{$\mathrm{CO}_{2}$} & 8.9 & 21.23 & 9.2 & 18.58 & 9.4 & 16.81 \\
\hline & \multicolumn{2}{|c|}{20} & \multicolumn{2}{|c|}{25} & \multicolumn{2}{|r|}{30} \\
\hline $\mathrm{t}, \mathrm{min}$ & $\begin{array}{c}\text { outlet } \\
\text { concentration, } \\
10^{-6}\end{array}$ & $\begin{array}{c}\text { removal } \\
\text { efficiency , \% }\end{array}$ & $\begin{array}{c}\text { outlet } \\
\text { concentration, } \\
10^{-6}\end{array}$ & $\begin{array}{c}\text { removal } \\
\text { efficiency , \% }\end{array}$ & $\begin{array}{c}\text { outlet } \\
\text { concentration, } \\
10^{-6}\end{array}$ & removal efficiency , \% \\
\hline $\mathrm{SO}_{2}$ & 7 & 99.22 & 8 & 99.10 & 12 & 98.66 \\
\hline $\mathrm{CO}_{2}$ & 9.6 & 15.04 & 9.8 & 13.27 & 10.2 & 9.73 \\
\hline
\end{tabular}

From Table 2, it can be shown that the removal efficiencies of DMSO+Mn (II) absorbent for $\mathrm{SO}_{2}$ are over $98 \%$ in the presence of $\mathrm{CO}_{2}$ within the absorption time of 0 to $30 \mathrm{~min}$, but only $9-21 \%$ removal efficiency for $\mathrm{CO}_{2}$, it reveals that DMSO+ $\mathrm{Mn}$ (II) absorbents have a good selective removal for $\mathrm{SO}_{2}$ in the presence of $\mathrm{CO}_{2}$.

Meanwhile another experiment is also carried out to examine the absorption of $\mathrm{SO}_{2}$ in the presence of $\mathrm{CO}_{2}$ and $\mathrm{SO}_{2}$ with pure DMSO and the similar results are obtained.

\subsubsection{The effect of absorbent of Mn (II)+DMSO on the removal efficiency of NOx}

The effect of absorbent of Mn (II)+DMSO on the removal efficiency of NOx is listed in Table 3.

Table 3 The effect of absorbent of Mn (II)+DMSO on the removal efficiency of NOx

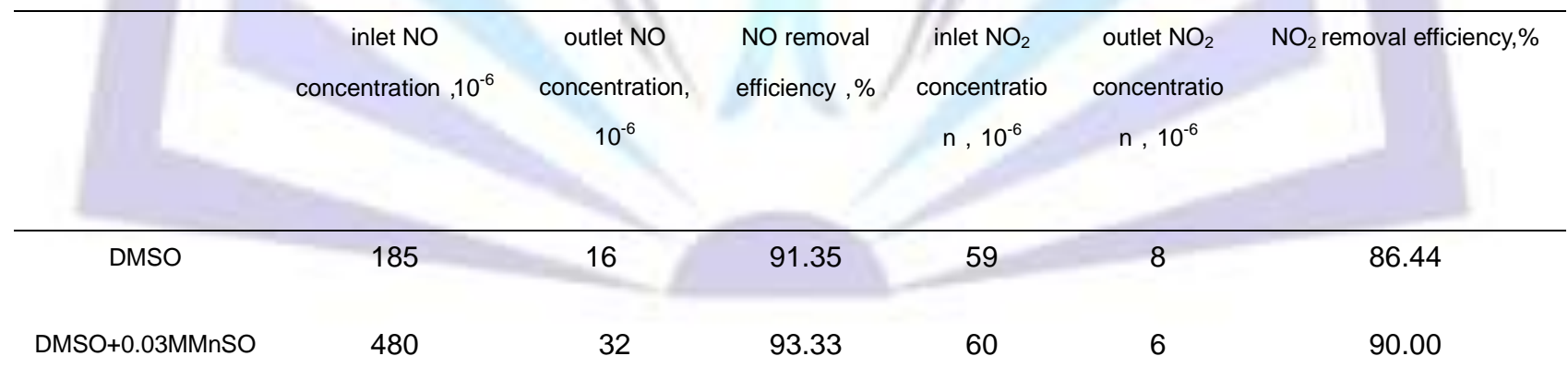

The results indicate that absorbent of $\mathrm{Mn}(\mathrm{II})+\mathrm{DMSO}$ has high the removal efficiency for NOx, and the addition of Mn (II) in DMSO can increase removal efficiency of NOx.

\subsubsection{The selectively absorption effect of $\mathrm{Mn}$ (II) + DMSO on removal efficiency of $\mathrm{SO}_{2}$ and $\mathrm{NO}_{x}$ in the presence of $\mathrm{CO}_{2}$}

Experiment condition: temperature $301.15 \mathrm{~K}$, gas flow: $130 \mathrm{~mL} \cdot \mathrm{min}^{-1}$. The results are listed in Table 4. 
Table 4 The selectivity absorption effect of $\mathrm{Mn}(\mathrm{II})+$ DMSO on removal efficiency of $\mathrm{SO}_{2}$ and $\mathrm{NO}_{\mathrm{x}}$ in the presence of $\mathrm{CO}_{2}$

\begin{tabular}{|c|c|c|c|c|c|c|c|c|c|}
\hline $\begin{array}{l}\mathrm{t}, \\
\min \end{array}$ & $\begin{array}{c}\text { inlet } \\
\text { concentration } \\
, 10^{6}\end{array}$ & $\begin{array}{c}\text { outlet } \\
\text { concentration } \\
, 10^{6}\end{array}$ & $\begin{array}{c}\text { removal } \\
\text { efficiency ,\% }\end{array}$ & $\begin{array}{c}\text { inlet } \\
\text { œncentration } \\
, 10^{6}\end{array}$ & $\begin{array}{c}\text { oullet } \\
\text { concentration } \\
, 10^{6}\end{array}$ & $\begin{array}{c}\text { removal } \\
\text { efficiency , \% }\end{array}$ & $\begin{array}{c}\text { inlet } \\
\text { concentration } \\
, 10^{6}\end{array}$ & $\begin{array}{c}\text { oullet } \\
\text { concentration } \\
, 10^{6}\end{array}$ & removal efficiency,$\%$ \\
\hline $\mathrm{SO}_{2}$ & 718 & 17 & 97.63 & 675 & 14 & 97.92 & 1274 & 21 & 98.35 \\
\hline $\mathrm{CO}_{2}$ & $12 \%$ & $9.5 \%$ & 20.83 & $10.1 \%$ & $8.5 \%$ & 15.84 & $9.7 \%$ & $7.8 \%$ & 19.58 \\
\hline $\mathrm{NO}_{2}$ & 85 & 8 & 90.59 & 70 & 6 & 91.42 & 50 & 5 & 90.00 \\
\hline NO & 403 & 38 & 91.00 & 445 & 43 & 90.33 & 436 & 40 & 90.82 \\
\hline
\end{tabular}

The results indicate that the removal efficiencies of $\mathrm{DMSO}+\mathrm{Mn}$ (II) absorbent for $\mathrm{SO}_{2}$ are over $97 \%$ in the presence of $\mathrm{CO}_{2}$, and for $\mathrm{NO}_{x}$ are over $90 \%$ in the presence of $\mathrm{CO}_{2}$.

\subsection{Result of the enlarged experiment}

\subsubsection{The effect of ratio of gas/liquid on the desulfurization selectivity}

The suitable gas /liquid (G/L) ratio is the key factors influencing removal efficiency of $\mathrm{SO}_{2}$, The effect of ratio of $\mathrm{G} / \mathrm{L}$ on the selectivity removal efficiency of $\mathrm{SO}_{2}$ is listed in Table 5 . The results showed the suitable gas /liquid ratio is 1:40-1:500.

Table 5. The experimental result of removing $\mathrm{SO}_{2}$ by $\mathrm{Mn}$ (II) + DMSO

\begin{tabular}{|c|c|c|c|c|c|c|c|c|c|c|c|c|c|}
\hline \multirow[t]{2}{*}{ No. } & \multirow[t]{2}{*}{$\begin{array}{c}\text { rate of } \\
\text { flow } / \mathrm{m}^{3} \cdot \mathrm{h}^{-} \\
1\end{array}$} & \multirow[t]{2}{*}{$\begin{array}{c}\text { ratio } \\
\text { of } \\
\mathrm{G} / \mathrm{L}\end{array}$} & \multirow[t]{2}{*}{$\begin{array}{l}\text { temper } \\
\text { ature } \\
{ }^{\circ} \mathrm{C}\end{array}$} & \multicolumn{2}{|c|}{$\begin{array}{c}\text { absorption } \\
\text { solution } \\
\text { concentration , molkg }\end{array}$} & \multicolumn{3}{|c|}{$\begin{array}{c}\text { inlet gas } \\
\text { composition,\% }\end{array}$} & \multicolumn{2}{|c|}{$\begin{array}{c}\text { outlet gas } \\
\text { composition,\% }\end{array}$} & \multicolumn{2}{|c|}{$\begin{array}{c}\text { removal } \\
\text { efficiency,\% }\end{array}$} & \multirow[t]{2}{*}{ selectivity } \\
\hline & & & & $\mathrm{SO}_{2}$ & $\mathrm{CO}_{2}$ & SO & $\mathrm{CO}$ & $\mathrm{O}_{2}$ & $\mathrm{SO}_{2}$ & $\mathrm{CO}_{2}$ & $\mathrm{SO}_{2}$ & $\mathrm{CO}_{2}$ & \\
\hline 1 & 0.04 & 40 & 25 & 0.048 & 0.00091 & 0.4 & 9.8 & 2.3 & 0.001 & 5.0 & 99.78 & 48.98 & 53.27 \\
\hline 2 & 0.1 & 100 & 25 & 0.061 & 0.00110 & 0.4 & 9.8 & 2.3 & 0.006 & 5.2 & 99.67 & 46.94 & 55.45 \\
\hline 3 & 0.2 & 200 & 25 & 0.129 & 0.00130 & $\begin{array}{c}0.4 \\
5\end{array}$ & 9.8 & 2.3 & $\begin{array}{c}0.019 \\
4\end{array}$ & 5.8 & 95.69 & 40.82 & 99.46 \\
\hline 4 & 0.25 & 250 & 25 & 0.132 & 0.00131 & $\begin{array}{c}0.4 \\
5\end{array}$ & 9.8 & 2.3 & $\begin{array}{c}0.027 \\
4\end{array}$ & 7.0 & 93.9 & 28.57 & 100.92 \\
\hline 5 & 0.04 & 40 & 30 & $\begin{array}{c}0.037 \\
9\end{array}$ & $\begin{array}{c}0.00080 \\
1\end{array}$ & $\begin{array}{c}0.4 \\
5\end{array}$ & 9.8 & 2.3 & $\begin{array}{c}0.001 \\
5\end{array}$ & 5.2 & 99.67 & 46.94 & 47.31 \\
\hline 6 & 0.1 & 100 & 30 & $\begin{array}{c}0.055 \\
1\end{array}$ & $\begin{array}{c}0.00090 \\
0\end{array}$ & $\begin{array}{c}0.4 \\
5\end{array}$ & 9.8 & 2.3 & $\begin{array}{c}0.007 \\
2\end{array}$ & 5.5 & 98.4 & 43.37 & 61.20 \\
\hline 7 & 0.2 & 200 & 30 & 0.129 & 0.00100 & $\begin{array}{c}0.4 \\
5\end{array}$ & 9.8 & 2.3 & 0.020 & 6.0 & 95.56 & 38.78 & 128.60 \\
\hline
\end{tabular}




\begin{tabular}{cccccccccccccc}
\hline 8 & 0.25 & 250 & 30 & 0.130 & 0.00110 & 0.4 & 9.8 & 2.3 & 0.041 & 7.2 & 90.88 & 26.53 & 118.45 \\
& & & & & & 5 & & & & & & & \\
9 & 0.04 & 40 & 40.5 & 0.025 & 0.00060 & 0.4 & 9.8 & 2.3 & 0.001 & 5.4 & 99.64 & 46.94 & 41.67 \\
& & & & 0 & 0 & 5 & & & 6 & & & &
\end{tabular}

$\begin{array}{llllllllllllll}10 & 0.1 & 100 & 40.5 & 0.038 & 0.00070 & 0.4 & 9.8 & 2.3 & 0.024 & 5.8 & 94.67 & 40.82 & 54.29\end{array}$

$0 \quad 0 \quad 5$

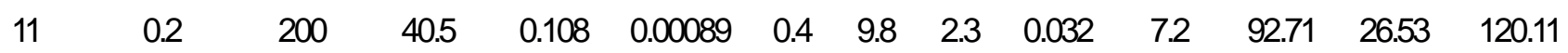

$\begin{array}{llllllllllllll}12 & 0.04 & 40 & 25 & 0.041 & 0.00070 & 0.4 & 7.4 & 2.2 & 0.000 & 3.8 & 99.86 & 48.65 & 59.09\end{array}$

$\begin{array}{llll}4 & 1 & 2 & 6\end{array}$

$\begin{array}{llllllllllllll}13 & 0.1 & 100 & 25 & 0.054 & 0.00090 & 0.4 & 7.4 & 2.2 & 0.002 & 4.2 & 99.53 & 43.24 & 60.00\end{array}$ $\begin{array}{llll}0 & 0 & 2 & 0\end{array}$

$\begin{array}{llllllllllllll}14 & 0.2 & 200 & 25 & 0.086 & 0.00110 & 0.4 & 7.4 & 2.2 & 0.004 & 5.0 & 99.03 & 32.43 & 78.55\end{array}$ $4 \quad 2$

$\begin{array}{llllllllllllll}15 & 0.04 & 40 & 30 & 0.035 & 0.00060 & 0.4 & 7.4 & 2.2 & 0.000 & 3.8 & 99.83 & 48.65 & 58.42\end{array}$ $\begin{array}{lllll}1 & 1 & 2 & 7\end{array}$

$\begin{array}{llllllllllllll}16 & 0.1 & 100 & 30 & 0.051 & 0.00080 & 0.4 & 7.4 & 2.2 & 0.002 & 4.8 & 99.46 & 33.33 & 63.78\end{array}$ $\begin{array}{llll}0 & 0 & 2 & 3\end{array}$

$\begin{array}{llllllllllllll}17 & 0.2 & 200 & 30 & 0.110 & 0.00090 & 0.4 & 7.4 & 2.2 & 0.004 & 5.2 & 98.91 & 27.78 & 122.33\end{array}$ $0 \quad 2 \quad 6$

$\begin{array}{llllllllllllll}18 & 0.04 & 40 & 40 & 0.021 & 0.00060 & 0.4 & 7.4 & 2.2 & 0.001 & 4.3 & 99.55 & 40.28 & 35.00\end{array}$ $0 \quad 0 \quad 2 \quad 9$

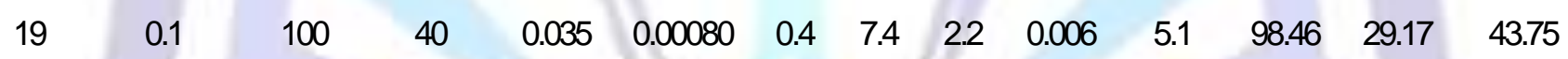
$\begin{array}{llll}0 & 0 & 2 & 5\end{array}$

$\begin{array}{llllllllllllll}20 & 0.2 & 200 & 40 & 0.089 & 0.00090 & 0.4 & 7.4 & 2.2 & 0.010 & 6.3 & 97.63 & 12.50 & 98.89\end{array}$ $0 \quad 0 \quad 2$

$\begin{array}{llllllllllllll}21 & 0.04 & 40 & 25 & 0.038 & 0.00110 & 0.4 & 19 . & 2.0 & 0.000 & 11.6 & 99.90 & 38.95 & 35.00\end{array}$ $\begin{array}{lllll}5 & 1 & 0 & 4\end{array}$

$\begin{array}{llllllllllllll}22 & 0.1 & 100 & 25 & 0.051 & 0.00130 & 0.4 & 19 . & 2.0 & 0.002 & 15.1 & 99.41 & 20.53 & 39.23\end{array}$

$\begin{array}{llll}0 & 1 & 0 & 4\end{array}$

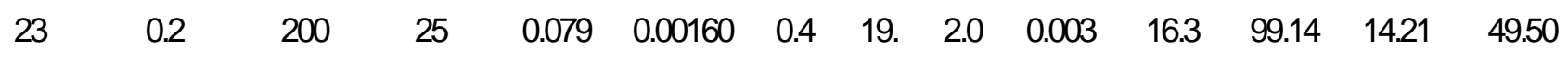
$2 \quad 1 \quad 0 \quad 5$

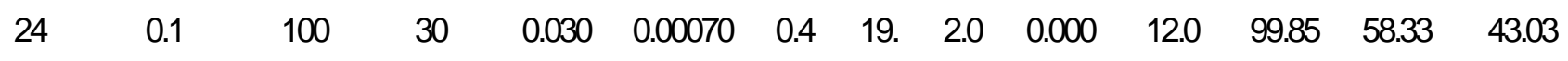

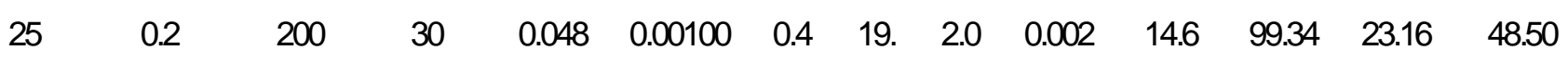
$5 \quad 1 \quad 0 \quad 7$ 


\begin{tabular}{cccccccccccccc}
\hline 26 & 0.3 & 300 & 30 & 0.098 & 0.00140 & 0.4 & 19. & 2.0 & 0.024 & 16.0 & 94.04 & 15.79 & 70.00 \\
& & & & 0 & & 1 & 0 & & 3 & & & & \\
27 & 0.1 & 100 & 40 & 0.020 & 0.00050 & 0.4 & 19. & 2.0 & 0.001 & 15.5 & 99.61 & 18.42 & 40.00 \\
& & & & 0 & 0 & 1 & 0 & & 6 & & & & \\
28 & 0.2 & 200 & 40 & 0.036 & 0.00080 & 0.4 & 19. & 2.0 & 0.006 & 15.9 & 98.53 & 16.32 & 45.50 \\
& & & & 4 & 0 & 1 & 0 & & 0 & & & & \\
29 & 0.3 & 300 & 40 & 0.079 & 0.00100 & 0.4 & 19. & 2.0 & 0.038 & 16.6 & 90.61 & 12.63 & 79.00 \\
& & & & 0 & & 1 & 0 & 3 & & & &
\end{tabular}

From Table 5, it can be found that removal efficiency of $\mathrm{SO}_{2}$ is influenced by gas /liquid ratio. If liquid flow is kept constant, the alteration of gas /liquid ratio has very little influence on removal efficiency of $\mathrm{SO}_{2}$, but the effect on the removal efficiency of $\mathrm{CO}_{2}$ is obvious.

\subsubsection{The effect of rate of gas flow on the desulfurization selectivity}

The effect of rate of gas flow on the selectivity removal efficiency of $\mathrm{SO}_{2}$ was studied with four rate of gas flow between $0.04 \mathrm{~m}^{3} / \mathrm{h}-0.25 \mathrm{~m}^{3} / \mathrm{h}$, and the result is listed in Table 5. From Table 5, it indicates that the removal efficiency of $\mathrm{CO}_{2}$ is lower; the selectivity is higher with the increase of the gas flow rate. Therefore, when the flue gas has high content of $\mathrm{CO}_{2}$, we can decrease the absorption for $\mathrm{CO}_{2}$ and increase the absorption of $\mathrm{SO}_{2}$ by using the increase of the gas rate.

\subsubsection{The effect of temperature on the desulfurization selectivity}

The effect of temperature on the selectivity removal efficiency of $\mathrm{SO}_{2}$ is listed in Table 5. The results indicate that the removal efficiency of $\mathrm{SO}_{2}$ is high with the decrease of temperature; therefore high removal efficiency of $\mathrm{SO}_{2}$ is obtained when $\mathrm{SO}_{2}$ absorption is kept at suitable low temperature.

\subsubsection{The effect of inlet gas composition on the desulfurization selectivity}

Three different gases, such as $\mathrm{SO}_{2}, \mathrm{CO}_{2}$ and $\mathrm{O}_{2}$ was mixed in the process of the experiments. Inlet $\mathrm{SO}_{2}$ concentration is about $0.4 \%, \mathrm{O}_{2}$ concentration is $2 \%$ or so, the inlet $\mathrm{CO}_{2}$ concentration is the change, the effect on the selectivity removal efficiency of $\mathrm{SO}_{2}$ in the presence of $\mathrm{CO}_{2}$ is studied. The result is listed in Table 5. From Table 5, it can be found that the removal efficiency of $\mathrm{SO}_{2}$ of $\mathrm{DMSO}+\mathrm{Mn}$ (II) absorbents are over $90 \%$ when the concentration of $\mathrm{CO}_{2} \mathrm{Changed}_{\text {, therefore }}$ the selectivity for $\mathrm{SO}_{2}$ removal does not decrease only increasing $\mathrm{CO}_{2}$ concentration. i.e. absorbents still have high purification efficiencies for $\mathrm{SO}_{2}$ in the presence of high content of $\mathrm{CO}_{2}$.

\subsubsection{The regeneration capacities of $\mathrm{Mn}$ (II) + DMSO}

The solution of being absorbed was desorbed at room temperature at the rate of $100 \mathrm{ml} / \mathrm{min}$, the desorption result of Mn (II) + DMSO is listed in Table 6 , it showed that the absorbents of Mn (II) + DMSO have good desorption efficiency , and the desorption efficiency are over $97 \%$ at room temperature.

Table 6 The desorption result of Mn (II) + DMSO

\begin{tabular}{ccccc}
\hline $\begin{array}{c}\mathrm{SO}_{2} \text { concentration } \\
\text { before desorption, } \\
\mathrm{mol} / \mathrm{kg}\end{array}$ & $\begin{array}{c}\text { desorption } \\
\text { temperature, } \\
{ }^{\circ} \mathrm{C}\end{array}$ & $\begin{array}{c}\text { rate of flow, } \\
\mathrm{ml} / \mathrm{min}\end{array}$ & $\begin{array}{c}\mathrm{SO}_{2} \text { concentration after } \\
\text { desorption, mol/kg }\end{array}$ & $\begin{array}{c}\text { desorption } \\
\text { efficiency, \% }\end{array}$ \\
\hline 0.1081 & 25 & 100 & 0.0025 & 97.67 \\
0.1101 & 25 & 100 & 0.0028 & 97.46 \\
\hline
\end{tabular}



0.1863
25
100
0.0041
97.80

\subsection{Mechanism Analysis}

The absorption process for $\mathrm{SO}_{2}$ containing DMSO $+\mathrm{Mn}$ (II) is a complicated mechanism coexisting of physical and chemical absorptions.

\subsubsection{Physical absorption}

DMSO is a polar aprotic organic solvent having a larger dipole moment (4.03 D). Its molecular structure is shown in Figure 3. $\mathrm{SO}_{2}$ and $\mathrm{NO}_{2}$ are polar gas molecules of $\mathrm{V}$-type molecular configuration and their molecular structure are shown in Figure 3. However $\mathrm{CO}_{2}$ is a symmetrical linear non-polar molecule, and its molecular configuration is shown in Figure 3.
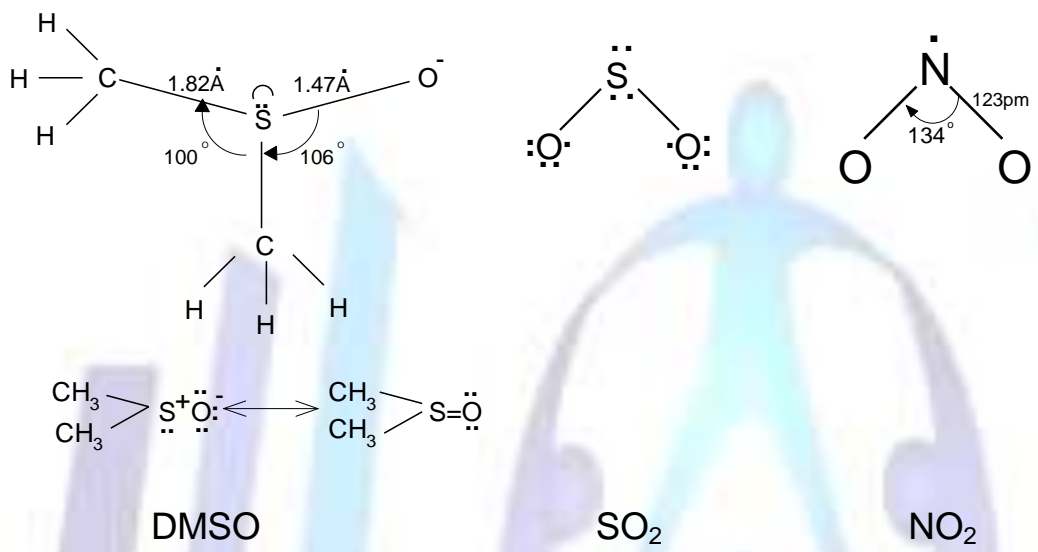

$$
: \ddot{\mathrm{O}}=\mathrm{C}=\ddot{\mathrm{O}}
$$

Fig. 3. Molecular structure for DMSO, $\mathrm{SO}_{2}, \mathrm{NO}_{2}$ and $\mathrm{CO}_{2}$

DMSO is a polar organic solvent with a rather large dipole matrix, $\mathrm{SO}_{2}$ and $\mathrm{NO}_{2}$ are also polar gas molecules, while $\mathrm{CO}_{2}$ is a non-polar gas molecule, therefore DMSO has a better absorption capacity on the polarity of the sulfur dioxide and nitrogen oxides, but less absorption capacity on the non-polar carbon dioxide. It agrees with the principle that like dissolves like.

Accordingly, the absorption model of $\mathrm{SO}_{2}$ in DMSO is shown in Figure 4 [9].

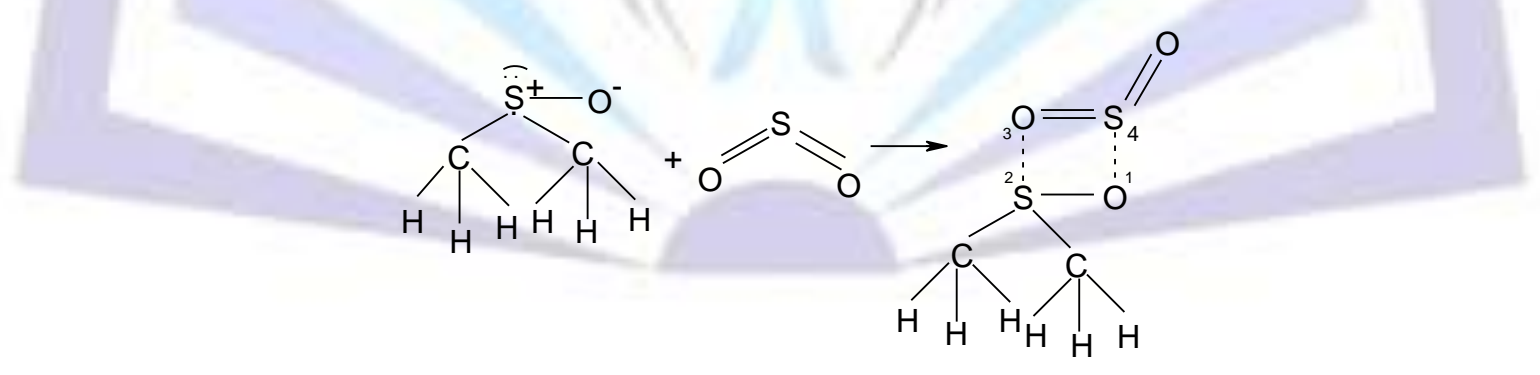

Fig. 4. The absorption model of $\mathrm{SO}_{2}$ in DMSO

\subsubsection{Chemical absorption}

After adding $\mathrm{Mn}$ (II) in DMSO, $\mathrm{SO}_{2}$ is oxidized to $\mathrm{H}_{2} \mathrm{SO}_{4}$ catalyzed by $\mathrm{MnSO}_{4}$.

The chemical reaction is expressed as follows $[10,11,12]$ :

$$
\mathrm{SO}_{2}+\frac{1}{2} \mathrm{O}_{2}+\mathrm{H}_{2} \mathrm{O} \stackrel{M_{n} \mathrm{SO}_{4}}{\longrightarrow} \mathrm{H}_{2} \mathrm{SO}_{4}
$$


The mixed absorbent has a good removal efficiency of $\mathrm{SO}_{2}$ and a good regeneration. Therefore the selected absorbent has a good future in $\mathrm{SO}_{2}$ removal.

\section{Conclusions}

The desulfurization selectivity experiment of DMSO $+\mathrm{Mn}$ (II) is studied. The result shows that the desulfurization absorbent has not only high desulfurization efficiency, but also good selectivity for $\mathrm{SO}_{2}$ and $\mathrm{NO}_{x}$ in the presence of $\mathrm{CO}_{2}$, the feasibility of desulfurization absorbent has been proved.

The effect of gas/liquid ratio, flow rate, temperature and inlet gas composition on the removal efficiency was determined, and the absorption and desorption experiment was investigated. The results indicated when liquid flow is constant, the alteration of gas /liquid ratio has very little influence on removal efficiency of $\mathrm{SO}_{2}$, but the effect on the removal efficiency of $\mathrm{CO}_{2}$ is obvious. The desulfurization absorbent still keep high desulfurization selectivity even if in high $\mathrm{CO}_{2}$ concentration. The removal efficiency of $\mathrm{SO}_{2}$ increases with the decrease of temperature; when the inlet gas composition changed, especially $\mathrm{CO}_{2}$ concentrations vary from 7-19\%, there is no obvious influence on the removal efficiency of $\mathrm{SO}_{2}$, it shows that the desulfurization absorbents still keep high desulfurization efficiencies in the presence of high content of $\mathrm{CO}_{2}$.

The result provided a valuable reference for the industrial application of removal of $\mathrm{SO}_{2}$ from flue gas.

\section{References}

[1] H. Li, W.R. Chen, D.Z. Liu, Environ. Protect. of Chem. Ind. 2002,22, 193-196.

[2] H. Li, W.R. Chen, Phy. and Chem. of L. 2006, 44, 83-93.

[3] H. Li, W.R. Chen, Phy. and Chem. of L. 2006, 44, 183-191.

[4] H. Li, W.R. Chen,. Phy. and Chem. of L. 2007, 45 57-65.

[5] Li, H. Phy. and Chem. of L. 2009, 47, 296-301.

[6] H. Li, W.R. Chen, D. Z. Liu, J. of Environ. Sci.. 2003, 15, 92-96.

[7] H. Li, W.R. Chen, Phy. and Chem. of L. 2007, 45, 207-213.

[8] H. Li, G. Q. Hu, X.S. Chen, Phy. and Chem. of L. 2010, 48, 652-660.

[9] R.H. Huang, Z.Y. Li, P. S. Sun, Yunnan Chemical Industry,1991, 22, 2-4.

[10] W. Pasiuk-Bronikowska, T. Bronikowski, Chem. Eng. Sci. 1981, 36, 215-219.

[11] A. Huss, P. K. Lim, J. Phys. Chem. 1982, 86, 4224-4228.

[12] C.M. Chen, Y. Zao, S.C. Ma, Y.C. Fu, J. North China Electric. Power Univ. 2001, 28, 80-82. 